\title{
Front Matter: Volume 8939
}

, "Front Matter: Volume 8939," Proc. SPIE 8939, Biomedical Vibrational Spectroscopy VI: Advances in Research and Industry, 893901 (11 March 2014); doi: $10.1117 / 12.2059830$

SPIE. Event: SPIE BiOS, 2014, San Francisco, California, United States 


\title{
Biomedical Vibrational Spectroscopy VI: Advances in Research and Industry
}

\author{
Anita Mahadevan-Jansen \\ Wolfgang Petrich \\ Editors
}

1-2 February 2014

San Francisco, California, United States

Sponsored and Published by

SPIE 
The papers included in this volume were part of the technical conference cited on the cover and title page. Papers were selected and subject to review by the editors and conference program committee. Some conference presentations may not be available for publication. The papers published in these proceedings reflect the work and thoughts of the authors and are published herein as submitted. The publisher is not responsible for the validity of the information or for any outcomes resulting from reliance thereon.

Please use the following format to cite material from this book:

Author(s), "Title of Paper," in Biomedical Vibrational Spectroscopy VI: Advances in Research and Industry, edited by Anita Mahadevan-Jansen, Wolfgang Petrich, Proceedings of SPIE Vol. 8939 (SPIE, Bellingham, WA, 2014) Article CID Number.

ISSN: 1605-7422

ISBN: 9780819498526

Published by

SPIE

P.O. Box 10, Bellingham, Washington 98227-0010 USA

Telephone +1 3606763290 (Pacific Time) · Fax +1 3606471445

SPIE.org

Copyright (C) 2014, Society of Photo-Optical Instrumentation Engineers.

Copying of material in this book for internal or personal use, or for the internal or personal use of specific clients, beyond the fair use provisions granted by the U.S. Copyright Law is authorized by SPIE subject to payment of copying fees. The Transactional Reporting Service base fee for this volume is $\$ 18.00$ per article (or portion thereof), which should be paid directly to the Copyright Clearance Center (CCC), 222 Rosewood Drive, Danvers, MA 01923. Payment may also be made electronically through CCC Online at copyright.com. Other copying for republication, resale, advertising or promotion, or any form of systematic or multiple reproduction of any material in this book is prohibited except with permission in writing from the publisher. The CCC fee code is $1605-7422 / 14 / \$ 18.00$.

Printed in the United States of America.

Publication of record for individual papers is online in the SPIE Digital Library.

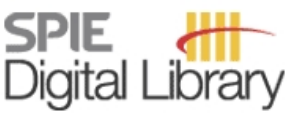

SPIEDigitalLibrary.org

Paper Numbering: Proceedings of SPIE follow an e-First publication model, with papers published first online and then in print and on CD-ROM. Papers are published as they are submitted and meet publication criteria. A unique, consistent, permanent citation identifier (CID) number is assigned to each article at the time of the first publication. Utilization of CIDs allows articles to be fully citable as soon as they are published online, and connects the same identifier to all online, print, and electronic versions of the publication. SPIE uses a six-digit CID article numbering system in which:

- The first four digits correspond to the SPIE volume number.

- The last two digits indicate publication order within the volume using a Base 36 numbering

system employing both numerals and letters. These two-number sets start with 00, 01, 02, 03, 04, $05,06,07,08,09,0 A, 0 B \ldots$. 0Z, followed by 10-1Z, 20-2Z, etc.

The CID Number appears on each page of the manuscript. The complete citation is used on the first page, and an abbreviated version on subsequent pages. Numbers in the index correspond to the last two digits of the six-digit CID Number. 


\section{Contents}

vii Conference Committee

\section{SESSION 1 CELLS}

893902 Analysis of virus infected cell by Raman spectroscopy and transmission electron microscopy [8939-1]

K. Moor, K. Ohtani, Kwansei Gakuin Univ. (Japan); D. Myrzakozha, O. Zhanserkenova, Kazakh National Agrarian Univ. (Kazakhstan); B. B. Andriana, H. Sato, Kwansei Gakuin Univ. (Japan)

893905 Differentiating the growth phases of single bacteria using Raman spectroscopy [8939-4]

S. A. Strola, P. R. Marcoux, E. Schultz, R. Perenon, CEA-LETI (France); A.-C. Simon,

I. Espagnon, CEA-LIST (France); C. P. Allier, J.-M. Dinten, CEA-LETI (France)

893906 Cell identification using Raman spectroscopy in combination with optical trapping and microfluidics [8939-5]

C. Krafft, S. Dochow, C. Beleites, Institut für Photonische Technologien e.V. (Germany);

J. Popp, Institut für Photonische Technologien e.V. (Germany) and Univ. Jena (Germany)

893907 Label-free haemogram using wavelength modulated Raman spectroscopy for identifying immune-cell subset [8939-6]

P. C. Ashok, B. B. Praveen, E. C. Campbell, K. Dholakia, S. J. Powis, Univ. of St. Andrews

(United Kingdom)

\section{SESSION 2 METHODS I}

893909 A new SERS: scattering enhanced Raman scattering [8939-8]

J. N. Bixler, V. V. Yakovlev, Texas A\&M Univ. (United States)

8939 OA SERS-barcoded colloidal gold NP assemblies as imaging agents for use in biodiagnostics [8939-9]

P. Dey, W. Olds, Queensland Univ. of Technology (Australia); I. Blakey, K. J. Thurecht, The Univ. of Queensland (Australia); E. L. Izake, P. M. Fredericks, Queensland Univ. of Technology (Australia)

8939 OD A novel method for single bacteria identification by Raman spectroscopy [8939-13] E. Schultz, CEA-LETI (France); A.-C. Simon, CEA-LIST (France); S. A. Strola, R. Perenon, CEALETI (France); I. Espagnon, CEA-LIST (France); C. Allier, P. Claustre, D. Jary, J.-M. Dinten, CEA-LETI (France) 
8939 OE Classification of oral cancers using Raman spectroscopy of serum [8939-14]

A. Sahu, S. Talathi, S. Sawant, C. M. Krishna, Advanced Ctr. for Treatment, Research and Education in Cancer (India)

8939 OF Raman spectroscopy for the assessment of acute myeloid leukemia: a proof of concept study [8939-15]

R. Vanna, Fondazione Don Carlo Gnocchi (Italy) and Univ. Twente (Netherlands);

C. Tresoldi, P. Ronchi, Fondazione San Raffaele del Monte Tabor (Italy); A. T. M. Lenferink, Univ. Twente (Netherlands); C. Morasso, D. Mehn, M. Bedoni, Fondazione Don Carlo Gnocchi (Italy); L. W. M. M. Terstappen, Univ. Twente (Netherlands); F. Ciceri, Fondazione San Raffaele del Monte Tabor (Italy); C. Otto, Univ. Twente (Netherlands); F. Gramatica, Fondazione Don Carlo Gnocchi (Italy)

8939 Ol Micro-Raman spectroscopy studies of changes in lipid composition in breast and prostate cancer cells treated with MPA and R1881 hormones [8939-18]

M. C. Potcoava, G. L. Futia, J. Aughenbaugh, I. R. Schlaepfer, E. A. Gibson, Univ. of Colorado, Denver (United States)

8939 0J Investigating the biochemical progression of liver disease through fibrosis, cirrhosis, dysplasia, and hepatocellular carcinoma using Fourier transform infrared spectroscopic imaging [8939-19]

H. Sreedhar, M. Pant, N. R. Ronquillo, B. Davidson, P. Nguyen, R. Chennuri, J. Choi, Univ. of Illinois at Chicago (United States); J. A. Herrera, Univ. of Wisconsin-Madison (United States); A. C. Hinojosa, M. Jin, A. Kajdacsy-Balla, G. Guzman, M. J. Walsh, Univ. of Illinois at Chicago (United States)

\section{SESSION 4 ONCOLOGY II}

8939 OL Combined information from Raman spectroscopy and optical coherence tomography for enhanced diagnostic accuracy in tissue discrimination [8939-21]

P. C. Ashok, B. B. Praveen, N. Bellini, A. Riches, K. Dholakia, Univ. of St. Andrews (United Kingdom); C. S. Herrington, Univ. of St. Andrews (United Kingdom) and Univ. of Dundee (United Kingdom)

8939 OM Real-time depth-resolved fiber optic Raman endoscopy for in vivo diagnosis of gastric precancer [8939-22]

M. S. Bergholt, W. Zheng, National Univ. of Singapore (Singapore); K. Y. Ho, K. G. Yeoh, M. Teh, J. B. Y. So, National Univ. of Singapore (Singapore) and National Univ. Hospital System (Singapore); Z. Huang, National Univ. of Singapore (Singapore)

\section{SESSION 5 APPLICATIONS BEYOND ONCOLOGY}

893900 The discrimination of fish egg quality and viability by using Raman spectroscopy [8939-24] M. Ishigaki, H. Sato, Kwansei Gakuin Univ. (Japan) 
8939 OP Monitoring the influence of antibiotic exposure using Raman spectroscopy [8939-25] O. Samek, P. Zemanek, S. Bernatova, J. Jezek, M. Sery, P. Jakl, M. Siler, Institute of Scientific Instruments of the ASCR, v.v.i. (Czech Republic); F. Ruzicka, Faculty of Medicine and St. Anne's Faculty Hospital (Czech Republic)

8939 OR Endoscopy-coupled Raman spectroscopy for in vivo discrimination of inflammatory bowel disease [8939-27]

I. J. Pence, Q. T. Nguyen, Vanderbilt Univ. (United States); X. Bi, The Univ. of Texas Health Science Ctr. at Houston (United States); A. J. Herline, D. M. Beaulieu, S. N. Horst,

D. A. Schwartz, A. Mahadevan-Jansen, Vanderbilt Univ. (United States)

8939 OT Fourier transform infrared spectroscopic imaging identifies early biochemical markers of tissue damage [8939-29]

V. K. Varma, S. Ohlander, P. Nguyen, C. Vendryes, S. Parthiban, Univ. of Illinois at Chicago (United States); B. Hamilton, M. C. Wallis, Univ. of Utah (United States); A. Kajdacsy-Balla, Univ. of Illinois at Chicago (United States); B. Hannaford, T. Lendvay, Univ. of Washington (United States); J. M. Hotaling, Univ. of Utah (United States); M. J. Walsh, Univ. of Illinois at Chicago (United States)

\section{SESSION 6 METHODS II}

8939 OU Multimodal fiber probe spectroscopy for tissue diagnostics applications: a combined Raman-fluorescence approach [8939-30]

R. Cicchi, Istituto Nazionale di Ottica-CNR (Italy) and European Lab. for Non-linear Spectroscopy (Italy); S. Anand, European Lab. for Non-linear Spectroscopy (Italy); S. Rossari, A. Sturiale, Univ. degli Studi di Firenze (Italy); F. Giordano, "Anna Meyer" Pediatric Hospital (Italy); V. De Giorgi, V. Maio, D. Massi, G. Nesi, A. M. Buccoliero, F. Tonelli, Univ. degli Studi di Firenze (Italy); R. Guerrini, "Anna Meyer" Pediatric Hospital (Italy); N. Pimpinelli, Univ. degli Studi di Firenze (Italy); F. S. Pavone, European Lab. for Non-linear Spectroscopy (Italy) and Univ. degli Studi di Firenze (Italy)

8939 OV Quantitative fiber optic Raman spectroscopy for tissue Raman measurements [8939-31] S. Duraipandian, M. Bergholt, W. Zheng, Z. Huang, National Univ. of Singapore (Singapore)

8939 OW A low background Raman probe for optical biopsy of brain tissue [8939-32] O. A. C. Stevens, Univ. of Bristol (United Kingdom); J. Hutchings, Univ. of Bristol (United Kingdom) and Gloucestershire Royal Hospital (United Kingdom); W. Gray, Cardiff Univ. (United Kingdom); J. C. Day, Univ. of Bristol (United Kingdom)

8939 OY Application of the shifted excitation Raman difference spectroscopy (SERDS) to the analysis of trace amounts of methanol in red wines [8939-34]

B. L. Volodin, S. Dolgy, V. S. Ban, PD-LD, Inc. (United States); D. Gracin, K. Juraić, Rudjer Boskovic Institute (Croatia); L. Gracin, Univ. of Zagreb (Croatia)

$89390 Z$ Rapid hyperspectral imaging in the mid-infrared [8939-35]

N. Kröger, A. Egl, M. Engel, N. Gretz, K. Haase, I. Herpich, S. Neudecker, A. Pucci,

A. Schönhals, W. Petrich, Univ. of Heidelberg (Germany) 
893912 Quantitative analysis of melamine by multi-way partial least squares model with twodimensional near-infrared correlation spectroscopy [8939-37]

R. Yang, Tianjin Univ. (China) and Tianjin Agricultural Univ. (China); R. Liu, K. XU, Tianjin Univ. (China); Y. Yang, Tianjin Agricultural Univ. (China)

893913 Detection of cancerous kidney tissue areas by means of infrared spectroscopy of intercellular fluid [8939-38]

V. Urboniene, F. Jankevicius, A. Zelvys, Vilnius Univ. (Lithuania); G. Steiner, Vilnius Univ. (Lithuania) and Technische Univ. Dresden (Germany); V. Sablinskas, Vilnius Univ. (Lithuania)

$893914 \quad$ Raman study of analysis for the states of maturation of neural cell [8939-39]

K. Hashimoto, S. N. Kudoh, H. Sato, Kwansei Gakuin Univ. (Japan)

Author Index 


\title{
Conference Committee
}

\author{
Symposium Chairs
}

James G. Fujimoto, Massachusetts Institute of Technology

(United States)

R. Rox Anderson, Wellman Center for Photomedicine, Massachusetts General Hospital (United States) and Harvard School of Medicine (United States)

Program Track Chairs

Tuan Vo-Dinh, Fitzpatrick Institute for Photonics, Duke University (United States)

Anita Mahadevan-Jansen, Vanderbilt University (United States)

Conference Chairs

Anita Mahadevan-Jansen, Vanderbilt University (United States)

Wolfgang Petrich, Roche Diagnostics GmbH (Germany)

Conference Program Committee

Andrew J. Berger, University of Rochester (United States)

Rohit Bhargava, University of Illinois at Urbana-Champaign (United States)

Airton Abrahão Martin, Universidade do Vale do Paraíba (Brazil)

Michael D. Morris, University of Michigan (United States)

Dieter Naumann, Robert Koch-Institut (Germany)

Jürgen Popp, Institut für Photonische Technologien e.V. (Germany)

Nicholas Stone, Gloucestershire Royal Hospital (United Kingdom)

Session Chairs

1 Cells

Anita Mahadevan-Jansen, Vanderbilt University (United States)

2 Methods I

Zhiwei Huang, National University of Singapore (Singapore)

3 Oncology I

Rohit Bhargava, University of Illinois at Urbana-Champaign (United States) 
4 Oncology II

Jürgen Popp, Institut für Photonische Technologien e.V. (Germany)

5 Applications Beyond Oncology

Haishan Zeng, The BC Cancer Agency Research Center (Canada)

6 Methods II

Wolfgang Petrich, Roche Diagnostics GmbH (Germany) 